Check for updates

Cite this: RSC Adv., 2017, 7, 23970

\title{
New diterpene alkaloids from the marine sponge Agelas mauritiana†
}

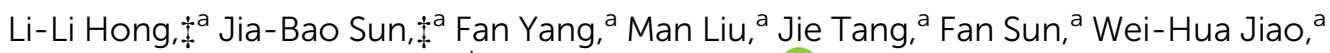 \\ Shu-Ping Wang, ${ }^{a}$ Wei Zhang ${ }^{* b}$ and Hou-Wen Lin (D *a
}

Chemical investigation of an ethanol extract of the sponge Agelas mauritiana led to the isolation and characterization of five new diterpene alkaloids, namely, (-)-8'-oxo-agelasine B (1), (+)-agelasine B (2), $(+)$ - $8^{\prime}$-oxo-agelasine $C(3)$, agelasine $V(4)$, and $(+)$ - $8^{\prime}$-oxo-agelasine $E(5)$, along with two known compounds, (-)- $8^{\prime}$-oxo-agelasine $D(6)$, and agelasine $D(7)$. The structures of these compounds were determined by interpretation of spectroscopic data and comparison with literature properties. Compounds 1 and 3-5 are the second example of $8^{\prime}$-oxo-agelasine analogs. Compounds 2 and 7 not only exhibited moderate cytotoxicity toward the cancer cell lines PC9, A549, HepG2, MCF-7, and U937 with $I_{50}$ values of $4.49-14.41 \mu \mathrm{M}$, but also showed potent antibacterial activities against a panel of methicillin-resistant Staphylococcus aureus (MRSA) clinical isolates with $\mathrm{MIC}_{90}$ values of $1-8 \mu \mathrm{g} \mathrm{mL}^{-1}$.

Received 1st March 2017 Accepted 21st April 2017

DOI: 10.1039/c7ra02547e

rsc.li/rsc-advances $8^{\prime}$-oxo-agelasine reported to date. ${ }^{12}$ As our continued exploration of this sponge in a search for structurally new products with promising bioactivities, we found that the $\mathrm{CH}_{2} \mathrm{Cl}_{2}$-soluble portion of an EtOH extract of the title sponge collected in March 2013, was cytotoxic against PC9, A549, and U937 cell lines in a Cell Counting Kit-8 (CCK-8) bioassay (8.5-10.5 $\mu \mathrm{g} \mathrm{mL}{ }^{-1}$ ) and showed moderate antibacterial activity against methicillinresistant Staphylococcus aureus (MRSA 2010-210) with $\mathrm{MIC}_{90}$ value of $1.0 \mu \mathrm{g} \mathrm{mL}{ }^{-1}$. Further bioactivity-guided fractionation of this $\mathrm{CH}_{2} \mathrm{Cl}_{2}$-soluble portion led to the isolation of five new compounds (1-5), as well as two known compounds (6 and 7). Compounds 1 and 3-5 represent the second example of $8^{\prime}$-oxoagelasine analogs. All isolated compounds (1-7) were evaluated for their cytotoxic and antibacterial activities. Herein, we describe the isolation, structure elucidation, and bioactivities of 1-7.

\section{Results and discussion}

Compound 1 was isolated as a pale yellow amorphous powder, and its molecular formula was deduced to be $\mathrm{C}_{26} \mathrm{H}_{39} \mathrm{~N}_{5} \mathrm{O}$ from the HRESIMS ion at $m / z 438.3232[\mathrm{M}+\mathrm{H}]^{+}$. The IR bands at $3325,1718 \mathrm{~cm}^{-1}$ implied the presence of amino and carbonyl functionalities, respectively. UV absorption at $275 \mathrm{~nm}$ was in agreement with literature value ${ }^{23}$ for purine moiety. The ${ }^{1} \mathrm{H}$ NMR spectrum of 1 displayed one deshielded aromatic siglet $\left(\delta_{\mathrm{H}} 8.17\right)$, two exchangeable siglets $\left(\delta_{\mathrm{H}} 7.36\right)$, one olefin siglet $\left(\delta_{\mathrm{H}}\right.$ 5.13), one olefin triplet $\left(\delta_{\mathrm{H}} 5.28\right)$, four methyl siglets $\left(\delta_{\mathrm{H}} 1.79\right.$, $0.95,0.68$, and 3.46), and two methyl doublets $\left(\delta_{\mathrm{H}} 0.75\right.$ and 1.53). The ${ }^{13} \mathrm{C}$ NMR and HSQC spectra of 1 revealed 26 carbon signals corresponding to six methyls (including one nitrogenbearing carbon at $\delta_{\mathrm{C}} 26.8$ ), seven methylenes, five methines, and eight quaternary carbons (including one carbonyl carbon at 
$\delta_{\mathrm{C}}$ 152.6). The above-mentioned NMR data exhibited close resemblance to those of agelasine $\mathrm{B},{ }^{17}$ except for the purine unit. The corresponding $\mathrm{sp}^{2}$ carbon in purine moiety at $\delta_{\mathrm{C}} 141.7$ in agelasine $\mathrm{B}^{17}$ was replaced by a carbonyl carbon at $\delta_{\mathrm{C}} 152.6$ in 1 , which was established by the HMBC cross-peaks of the nitrogen methyl protons $\left(\delta_{\mathrm{H}} 3.46\right)$ and $\mathrm{C}-4^{\prime}\left(\delta_{\mathrm{C}} 148.3\right)$ and $\mathrm{C}-8^{\prime}\left(\delta_{\mathrm{C}} 152.6\right)$, and of the aromatic proton $\left(\delta_{\mathrm{H}} 8.17\right)$ and $\mathrm{C}-2^{\prime}\left(\delta_{\mathrm{C}} 146.3\right), \mathrm{C}-4^{\prime}\left(\delta_{\mathrm{C}}\right.$ 148.3), and $\mathrm{C}^{\prime} 5^{\prime}\left(\delta_{\mathrm{C}}\right.$ 105.4) (Fig. 2). Moreover, a ${ }^{1} \mathrm{H}-{ }^{15} \mathrm{~N}$ HMBC experiment was conducted to confirm this 8-oxo-9- $\mathrm{N}$-methyladenine moiety. The observed ${ }^{1} \mathrm{H}-{ }^{13} \mathrm{~N}$ HMBC correlations of $\mathrm{H}-\mathrm{NCH}_{3} / \mathrm{N}-9^{\prime}\left(\delta_{\mathrm{N}} 127.8\right), \mathrm{H}_{2}-15\left(\delta_{\mathrm{H}} 4.63\right) / \mathrm{N}-7^{\prime}\left(\delta_{\mathrm{N}} 118.2\right), \mathrm{H}-2^{\prime}\left(\delta_{\mathrm{H}}\right.$ $8.17) / \mathrm{N}-1^{\prime}\left(\delta_{\mathrm{N}} 193.3\right)$, and $\mathrm{N}-3^{\prime}\left(\delta_{\mathrm{N}} 224.3\right)$ further prove this point. The rest $\mathrm{C}_{20} \mathrm{H}_{33}$ alkyl skeleton was assigned to have a clerodane skeleton by analysis of 2D NMR data (Fig. 2). In addition, HMBC correlations from two methylene protons $\left(\delta_{\mathrm{H}} 4.63\right)$ to $\mathrm{C}-13\left(\delta_{\mathrm{C}}\right.$ 144.0), $\mathrm{C}-5^{\prime}\left(\delta_{\mathrm{C}} 105.4\right)$, and $\mathrm{C}-8^{\prime}\left(\delta_{\mathrm{C}} 152.6\right)$ suggested that the 9 $\mathrm{N}$-methyladenine was attached to C-15 via $\mathrm{N}-7^{\prime}$.

The relative configuration of $\mathbf{1}$ was deduced from NOESY spectroscopic data (Fig. 3). The NOESY correlations of $\mathrm{H}_{2}-15\left(\delta_{\mathrm{H}}\right.$ 4.63) $/ \mathrm{H}_{3}-16\left(\delta_{\mathrm{H}} 1.79\right)$ and the chemical shift of $\mathrm{C}-16\left(\delta_{\mathrm{C}} 16.9\right)$ indicated the $13 E$-configuration of the double bond $\Delta .^{\mathbf{1 3 , 1 4}}$ Cross-peaks of $\mathrm{H}_{3}-19\left(\delta_{\mathrm{H}} 0.95\right) / \mathrm{H}_{3}-20\left(\delta_{\mathrm{H}} 0.68\right)$ and $\mathrm{H}-6 \mathrm{a}\left(\delta_{\mathrm{H}}\right.$ $1.66), \mathrm{H}_{3}-17\left(\delta_{\mathrm{H}} 0.75\right) / \mathrm{H}_{3}-20, \mathrm{H}-10\left(\delta_{\mathrm{H}} 1.27\right) / \mathrm{H}-11 \mathrm{a}\left(\delta_{\mathrm{H}} 1.48\right), \mathrm{H}-$ $12 \mathrm{~b}\left(\delta_{\mathrm{H}} 1.84\right)$, and $\mathrm{H}-6 \mathrm{~b}\left(\delta_{\mathrm{H}} 1.12\right)$, and $\mathrm{H}-6 \mathrm{~b} / \mathrm{H}-8\left(\delta_{\mathrm{H}} 1.40\right)$ indicated that $\mathrm{H}_{3}-17, \mathrm{H}_{3}-19, \mathrm{H}-6 \mathrm{a}$, and $\mathrm{H}_{3}-20$ were $\alpha$-oriented while $\mathrm{H}-8, \mathrm{H}-6 \mathrm{~b}, \mathrm{H}-10$, and $\mathrm{H}_{2}-11$ were $\beta$-oriented. Further comparison of the $[\alpha]_{\mathrm{D}}^{25}$ values of $\mathbf{1}(-33.9, \mathrm{MeOH})$ with that of agelasine $\mathrm{B}\left(-21.5, \mathrm{MeOH}^{17}\right.$ and $\left.-27.2^{27}\right)$ suggested the absolute configuration of 1 was probably identical to agelasine B since they had the same relative stereochemistry and the same sign of specific rotation. Thus, the structure of $(-)-8^{\prime}$-oxo-agelasine $\mathrm{B}$ was concluded to be shown in Fig. 1.

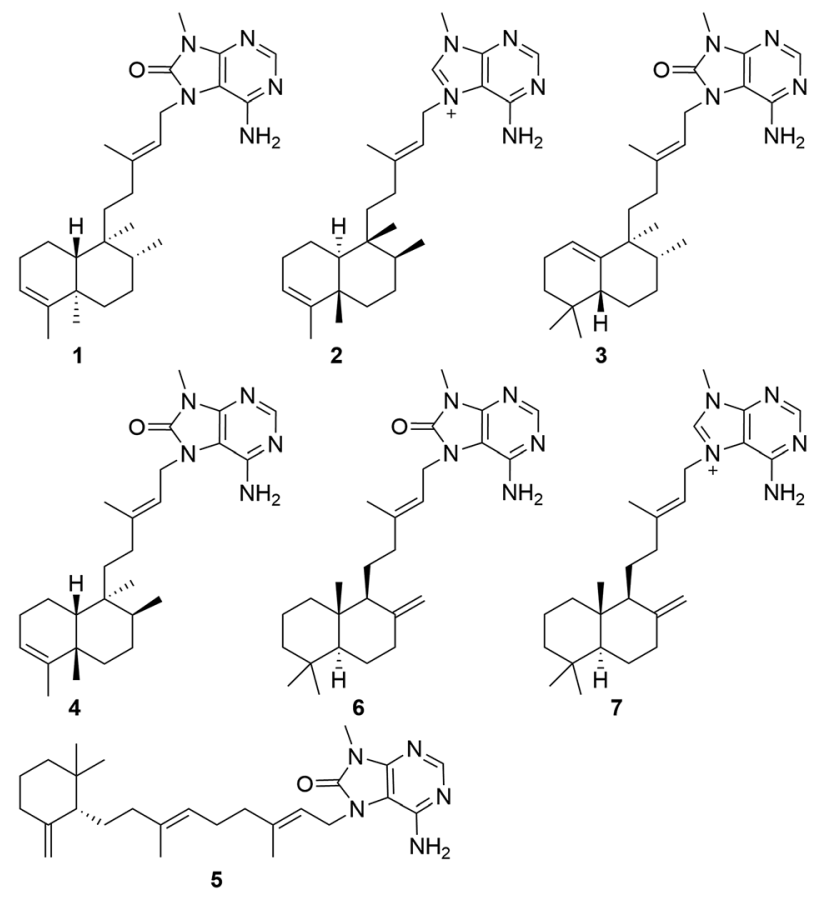

Fig. 1 The structures of compounds 1-7 from Agelas mauritiana.
Compound 2, a white amorphous powder, possessed a molecular formula of $\mathrm{C}_{26} \mathrm{H}_{39} \mathrm{~N}_{5}$, according to its ${ }^{13} \mathrm{C}$ NMR and HRESIMS ( $m / z 422.3280[\mathrm{M}+\mathrm{H}]^{+}$, calcd for $\left.\mathrm{C}_{26} \mathrm{H}_{40} \mathrm{~N}_{5}, 422.3284\right)$ data. Detailed analysis of the 1D and 2D NMR spectral data revealed that the planar structure of 2 was the same as agelasine B (Fig. 2). ${ }^{17}$ The double bond between C-13 ( $\left.\delta_{\mathrm{C}} 146.2\right)$ and C-14 $\left(\delta_{\mathrm{C}} 114.9\right)$ possessed the $E$-geometry, which was established by the NOESY correlations of $\mathrm{H}_{2}-15\left(\delta_{\mathrm{H}} 5.16\right) / \mathrm{H}_{3}-16\left(\delta_{\mathrm{H}} 1.79\right)$ and $\mathrm{H}-$ $14\left(\delta_{\mathrm{H}} 5.45\right) / \mathrm{H}_{2}-12\left(\delta_{\mathrm{H}} 1.97, \delta_{\mathrm{H}} 1.87\right)$ and the chemical shift of C$16\left(\delta_{\mathrm{C}} 16.7\right)$. Moreover, the $\alpha$-configurations of $\mathrm{H}-6 \mathrm{~b}\left(\delta_{\mathrm{H}} 1.10\right)$ and $\mathrm{H}-10\left(\delta_{\mathrm{H}} 1.29\right)$ were derived from NOESY correlations for $\mathrm{H}$ $6 \mathrm{~b} / \mathrm{H}-10$, while the $\beta$-configurations of $\mathrm{H}-6 \mathrm{a}\left(\delta_{\mathrm{H}} 1.65\right), \mathrm{H}_{3}-17\left(\delta_{\mathrm{H}}\right.$ $0.78), \mathrm{H}_{3}-19\left(\delta_{\mathrm{H}} 0.95\right)$, and $\mathrm{H}_{3}-20\left(\delta_{\mathrm{H}} 0.70\right)$ were implied from NOESY cross-peaks of $\mathrm{H}_{3}-19 / \mathrm{H}-6 \mathrm{a}$ and $\mathrm{H}_{3}-20$ and $\mathrm{H}_{3}-17 / \mathrm{H}_{3}-20$ (Fig. 4). The aforementioned data suggested 2 have identical
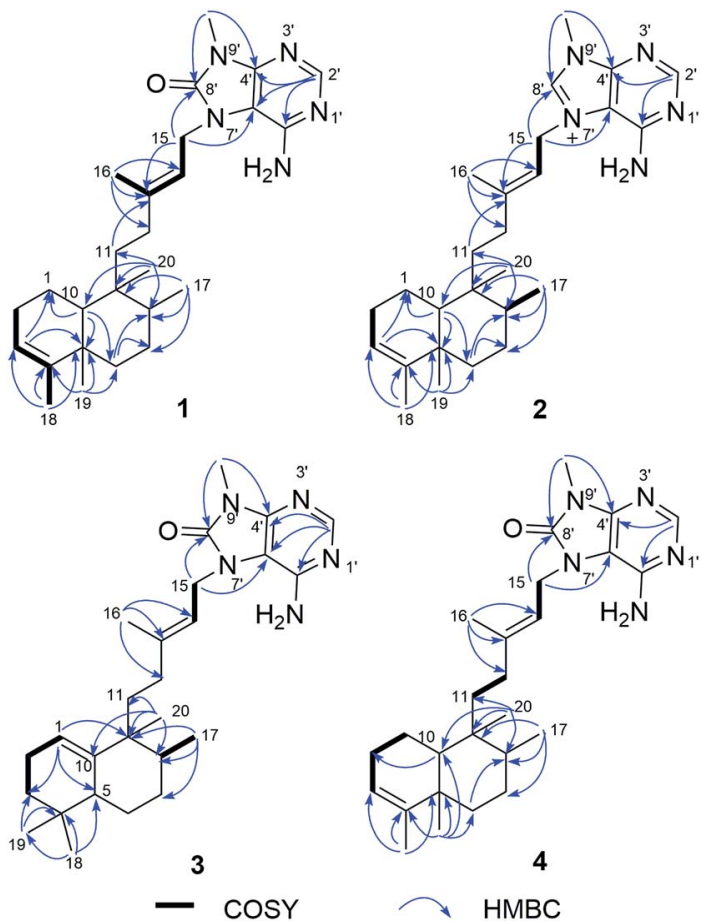

Fig. 2 Key ${ }^{1} \mathrm{H}-{ }^{1} \mathrm{H}$ COSY and $\mathrm{HMBC}$ correlations of compounds 1-4.

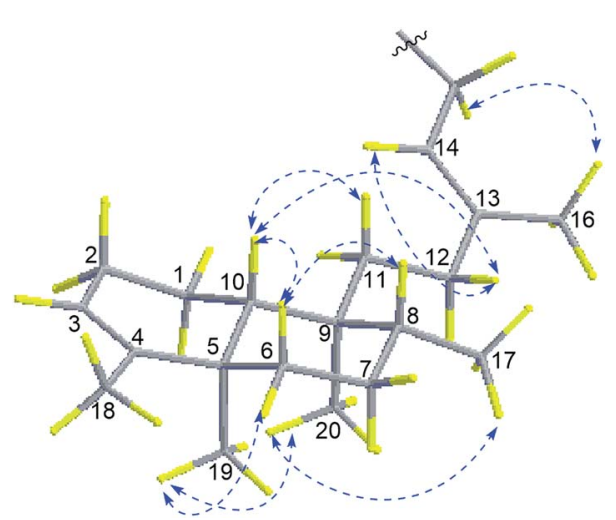

Fig. 3 Key NOESY correlations of compound 1. 


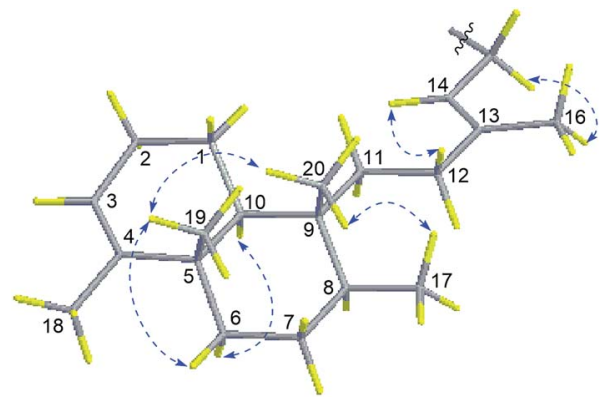

Fig. 4 Key NOESY correlations of compound 2.

relative configuration with agelasine $\mathrm{B}$. However, the opposite optical rotation data for them $\left[2\left([\alpha]_{\mathrm{D}}^{30}+22.7, \mathrm{MeOH}\right)\right.$, agelasine $\mathrm{B}\left([\alpha]_{\mathrm{D}}^{25}-21.5, \mathrm{MeOH}^{17}\right.$ and $\left.\left.[\alpha]_{\mathrm{D}}^{25}-27.2^{27}\right)\right]$ suggest 2 differed in absolute configuration at chiral centers with agelasine $B$. Thus, the structure of $\mathbf{2}$ was established as a stereoisomer of agelasine $\mathrm{B}$ and named $(+)$-agelasine $\mathrm{B}$.

Compound 3 showed a $[\mathrm{M}+\mathrm{H}]^{+}$ion peak at $\mathrm{m} / \mathrm{z} 438.3231$ in the HRESIMS, corresponding to a molecular formula of $\mathrm{C}_{26} \mathrm{H}_{39} \mathrm{~N}_{5} \mathrm{O}$. Comparison of the ${ }^{1} \mathrm{H}$ and ${ }^{13} \mathrm{C}$ NMR spectroscopic data (Tables 1 and 2) of compound 2 suggested a rearranged labdane skeleton for $\mathbf{3}$, which was further supported by the
HMBC correlations from $\mathrm{H}_{3}-17\left(\delta_{\mathrm{H}} 0.83\right)$ to C-7 $\left(\delta_{\mathrm{C}} 31.2\right)$, C-8 $\left(\delta_{\mathrm{C}}\right.$ $44.5)$, and $\mathrm{C}-9\left(\delta_{\mathrm{C}} 42.5\right)$, from $\mathrm{H}_{3}-20\left(\delta_{\mathrm{H}} 1.00\right)$ to C-8, C-9, C-10 $\left(\delta_{\mathrm{C}}\right.$ 145.4), and C-11 $\left(\delta_{\mathrm{C}} 29.6\right)$, from $\mathrm{H}_{3}-18\left(\delta_{\mathrm{H}} 0.84\right)$ to $\mathrm{C}-3\left(\delta_{\mathrm{C}} 31.3\right)$, $\mathrm{C}-4\left(\delta_{\mathrm{C}} 31.2\right), \mathrm{C}-5\left(\delta_{\mathrm{C}} 43.8\right)$, and C-19 $\left(\delta_{\mathrm{C}} 27.8\right)$, from $\mathrm{H}_{3}-19\left(\delta_{\mathrm{H}}\right.$ $0.84)$ to $\mathrm{C}-3, \mathrm{C}-4, \mathrm{C}-5$, and $\mathrm{C}-18\left(\delta_{\mathrm{C}} 27.8\right)$, from $\mathrm{H}-1\left(\delta_{\mathrm{H}} 5.34\right)$ to C$3, \mathrm{C}-5$, and C-9, and from $\mathrm{H}-5\left(\delta_{\mathrm{H}} 1.49\right)$ to $\mathrm{C}-1\left(\delta_{\mathrm{C}} 117.6\right), \mathrm{C}-3, \mathrm{C}-7$, $\mathrm{C}-10\left(\delta_{\mathrm{C}} 145.4\right), \mathrm{C}-18$, and C-19 (Fig. 2). The 13E-configuration of the double bond $\Delta^{\mathbf{1 3 , 1 4}}$ was inferred from the NOESY correlations of $\mathrm{H}_{2}-15\left(\delta_{\mathrm{H}} 4.65\right) / \mathrm{H}_{3}-16\left(\delta_{\mathrm{H}} 1.79\right)$ and $\mathrm{H}-14\left(\delta_{\mathrm{H}} 5.27\right) / \mathrm{H}_{2}-12$ $\left(\delta_{\mathrm{H}} 1.81, \delta_{\mathrm{H}} 1.72\right)$ and the chemical shift of C-16 $\left(\delta_{\mathrm{C}} 17.0\right)$. The NOESY correlations of $\mathrm{H}_{3}-17 / \mathrm{H}_{3}-20$ and $\mathrm{H}-6 \mathrm{a}\left(\delta_{\mathrm{H}} 1.78\right)$ indicated the $\beta$-orientation of $\mathrm{H}_{3}-17, \mathrm{H}-6 \mathrm{a}$, and $\mathrm{H}_{3}-20$, while the crosspeaks of $\mathrm{H}-5 / \mathrm{H}-6 \mathrm{~b}\left(\delta_{\mathrm{H}} 1.73\right)$ and $\mathrm{H}-8\left(\delta_{\mathrm{H}} 1.28\right)$ suggested these protons are $\alpha$-oriented, establishing the relative configurations of 3 (Fig. 5), in consonance with those of the synthesis product (+)-agelasine C. ${ }^{28}$ The absolute configurations of 3 was determined by comparison of its optical rotation $[\alpha]_{\mathrm{D}}^{25}+29(\mathrm{MeOH})$ and the synthesis product $(+)$-agelasine $\mathrm{C}[\alpha]_{\mathrm{D}}^{22}+25(\mathrm{MeOH})$. Therefore, the structure of $(+)-8^{\prime}$-oxo-agelasine $\mathrm{C}(3)$ was defined as shown in Fig. 1.

Compound 4 had a molecular formula of $\mathrm{C}_{26} \mathrm{H}_{39} \mathrm{~N}_{5} \mathrm{O}$ based on the $[\mathrm{M}+\mathrm{H}]^{+}$ion at $m / z 438.3230$ (calcd for $\mathrm{C}_{26} \mathrm{H}_{40} \mathrm{~N}_{5} \mathrm{O}$, 438.3233) in the HRESIMS. Extensive analysis of HMBC and COSY correlations revealed that compound 4 shared the same planar structure as 1 (Fig. 2). The NOESY correlation of $\mathrm{H}_{2}-15$

Table $1{ }^{1} \mathrm{H}$ NMR spectroscopic data for compounds $1-5$ ( $\delta$ in ppm, $J$ in $\mathrm{Hz}$ )

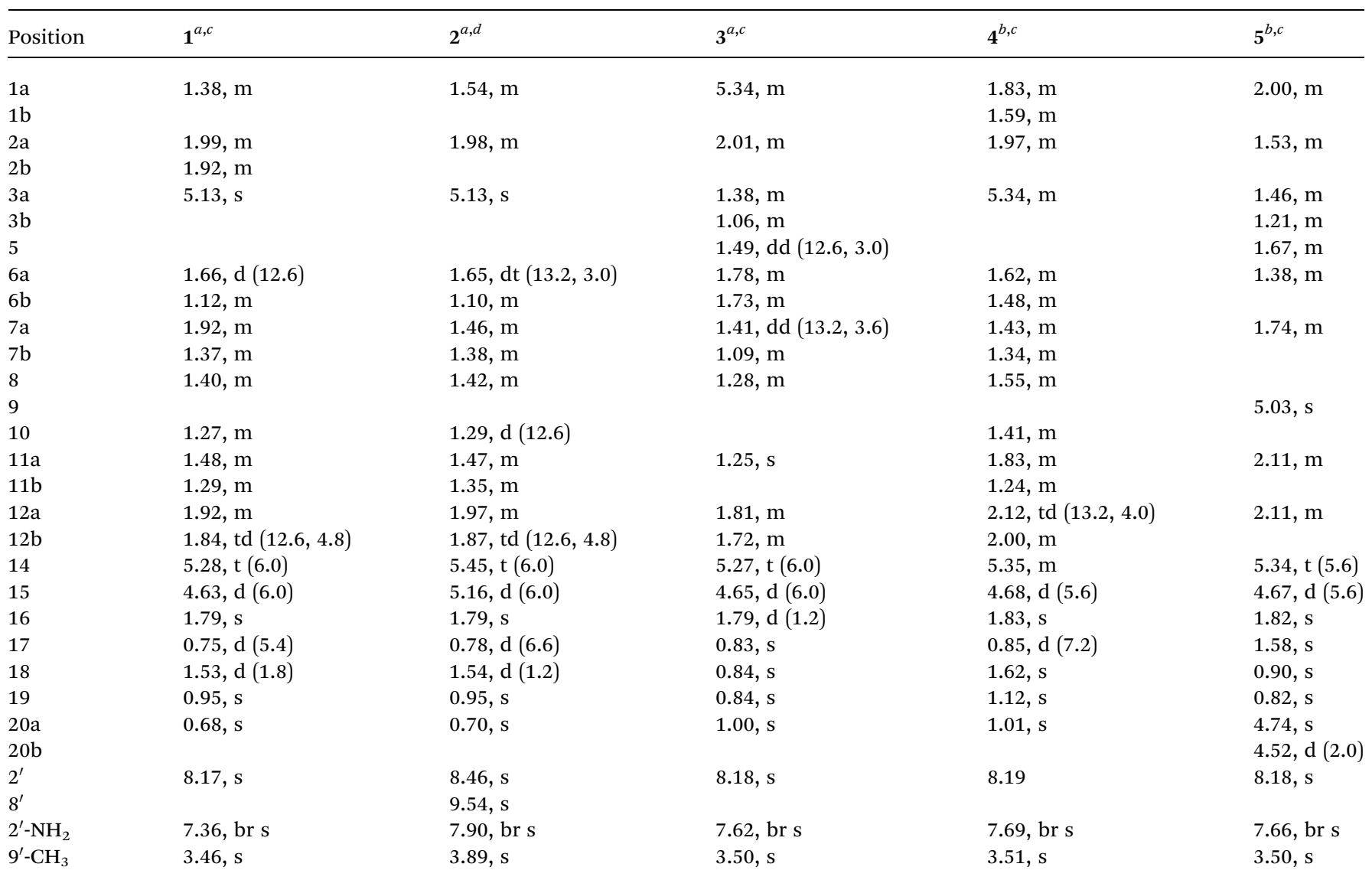

${ }^{a}$ Measured at $600 \mathrm{MHz} .{ }^{b}$ Measured at $400 \mathrm{MHz} .{ }^{c}$ Measured in $\mathrm{CDCl}_{3} .{ }^{d}$ Measured in DMSO- $d_{6}$. 
Table $2{ }^{13}$ C NMR spectroscopic data for compounds $1-5$ ( $\delta$ in ppm)

\begin{tabular}{|c|c|c|c|c|c|}
\hline Position & $\mathbf{1}^{a, c}$ & $2^{a, d}$ & $3^{a, c}$ & $4^{b, c}$ & $5^{b, c}$ \\
\hline 1 & $18.3, \mathrm{CH}_{2}$ & $17.8, \mathrm{CH}_{2}$ & 117.6, CH & $19.9, \mathrm{CH}_{2}$ & $32.5, \mathrm{CH}_{2}$ \\
\hline 2 & $26.8, \mathrm{CH}_{2}$ & 26.3, $\mathrm{CH}_{2}$ & $23.2, \mathrm{CH}_{2}$ & 25.7, $\mathrm{CH}_{2}$ & 23.7, $\mathrm{CH}_{2}$ \\
\hline 3 & $120.3, \mathrm{CH}$ & $120.2, \mathrm{CH}$ & $31.3, \mathrm{CH}_{2}$ & 122.5, CH & $36.3, \mathrm{CH}_{2}$ \\
\hline 4 & 144.3, C & 143.6, C & $31.2, \mathrm{C}$ & $141.8, \mathrm{C}$ & $34.9, \mathrm{C}$ \\
\hline 5 & 38.1, C & $37.6, \mathrm{C}$ & $43.8, \mathrm{CH}$ & $38.7, \mathrm{C}$ & $53.6, \mathrm{CH}$ \\
\hline 6 & 36.7, $\mathrm{CH}_{2}$ & $36.2, \mathrm{CH}_{2}$ & $30.1, \mathrm{CH}_{2}$ & 32.1, $\mathrm{CH}_{2}$ & $24.8, \mathrm{CH}_{2}$ \\
\hline 7 & $27.4, \mathrm{CH}_{2}$ & $27.0, \mathrm{CH}_{2}$ & $31.2, \mathrm{CH}_{2}$ & $27.2, \mathrm{CH}_{2}$ & $38.2, \mathrm{CH}_{2}$ \\
\hline 8 & $36.2, \mathrm{CH}$ & $35.7, \mathrm{CH}$ & $44.5, \mathrm{CH}$ & $37.4, \mathrm{CH}$ & 137.0, C \\
\hline 9 & $38.6, \mathrm{C}$ & $38.2, \mathrm{C}$ & $42.5, \mathrm{C}$ & $38.7, \mathrm{C}$ & 122.5, CH \\
\hline 10 & $46.4, \mathrm{CH}$ & $45.9, \mathrm{CH}$ & $145.4, \mathrm{C}$ & $44.6, \mathrm{CH}$ & 149.3, C \\
\hline 11 & 36.4, $\mathrm{CH}_{2}$ & $35.8, \mathrm{CH}_{2}$ & 29.6, $\mathrm{CH}_{2}$ & $36.0, \mathrm{CH}_{2}$ & 26.1, $\mathrm{CH}_{2}$ \\
\hline 12 & 33.0, $\mathrm{CH}_{2}$ & $32.5, \mathrm{CH}_{2}$ & $33.9, \mathrm{CH}_{2}$ & $33.7, \mathrm{CH}_{2}$ & $39.5, \mathrm{CH}_{2}$ \\
\hline 13 & $144.0, \mathrm{C}$ & 146.2, C & 144.7, C & 144.7, C & 143.3, C \\
\hline 14 & $119.5, \mathrm{CH}$ & 114.9, CH & $119.3, \mathrm{CH}$ & $119.5, \mathrm{CH}$ & $119.8, \mathrm{CH}$ \\
\hline 15 & $40.5, \mathrm{CH}_{2}$ & $47.0, \mathrm{CH}_{2}$ & $40.6, \mathrm{CH}_{2}$ & $40.6, \mathrm{CH}_{2}$ & $40.6, \mathrm{CH}_{2}$ \\
\hline 16 & $16.9, \mathrm{CH}_{3}$ & $16.7, \mathrm{CH}_{3}$ & $17.0, \mathrm{CH}_{3}$ & $17.1, \mathrm{CH}_{3}$ & $16.9, \mathrm{CH}_{3}$ \\
\hline 17 & $15.9, \mathrm{CH}_{3}$ & $15.8, \mathrm{CH}_{3}$ & $16.3, \mathrm{CH}_{3}$ & $15.3, \mathrm{CH}_{3}$ & $16.1, \mathrm{CH}_{3}$ \\
\hline 18 & $17.9, \mathrm{CH}_{3}$ & 17.7, $\mathrm{CH}_{3}$ & $27.8, \mathrm{CH}_{3}$ & $19.3, \mathrm{CH}_{3}$ & 28.4, $\mathrm{CH}_{3}$ \\
\hline 19 & $19.8, \mathrm{CH}_{3}$ & $19.6, \mathrm{CH}_{3}$ & $27.8, \mathrm{CH}_{3}$ & $28.0, \mathrm{CH}_{3}$ & $26.2, \mathrm{CH}_{3}$ \\
\hline 20 & $18.2, \mathrm{CH}_{3}$ & $18.1, \mathrm{CH}_{3}$ & $23.0, \mathrm{CH}_{3}$ & $26.2, \mathrm{CH}_{3}$ & $108.8, \mathrm{CH}_{2}$ \\
\hline $2^{\prime}$ & $146.3, \mathrm{CH}$ & 155.4, CH & $145.8, \mathrm{CH}$ & 145.6, CH & 145.6, CH \\
\hline $4^{\prime}$ & $148.3, \mathrm{C}$ & 148.9, C & 148.3, C & 148.3, C & $148.3, \mathrm{C}$ \\
\hline $5^{\prime}$ & $105.4, \mathrm{C}$ & 109.2, C & $105.4, \mathrm{C}$ & $105.4, \mathrm{C}$ & $105.4, \mathrm{C}$ \\
\hline $6^{\prime}$ & 143.6, C & 152.3, C & 143.5, C & 143.4, C & 143.3, C \\
\hline $8^{\prime}$ & $152.6, \mathrm{C}$ & $140.9, \mathrm{CH}$ & $152.6, \mathrm{C}$ & $152.6, \mathrm{C}$ & $152.6, \mathrm{C}$ \\
\hline $9^{\prime}-\mathrm{CH}_{3}$ & $26.8, \mathrm{CH}_{3}$ & 31.4, $\mathrm{CH}_{3}$ & $26.9, \mathrm{CH}_{3}$ & $26.9, \mathrm{CH}_{3}$ & $26.9, \mathrm{CH}_{3}$ \\
\hline
\end{tabular}

${ }^{a}$ Measured at $150 \mathrm{MHz} .{ }^{b}$ Measured at $100 \mathrm{MHz} .{ }^{c}$ Measured in $\mathrm{CDCl}_{3}$. ${ }^{d}$ Measured in DMSO- $d_{6}$.

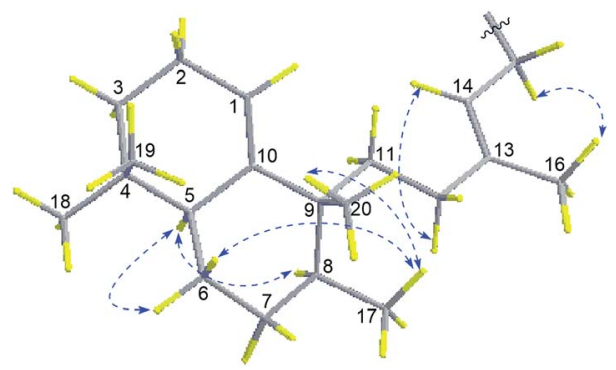

Fig. 5 Key NOESY correlations of compound 3.

$\left(\delta_{\mathrm{H}} 4.68\right) / \mathrm{H}_{3}-16\left(\delta_{\mathrm{H}} 1.83\right)$ and $\mathrm{H}-14\left(\delta_{\mathrm{H}} 5.35\right) / \mathrm{H}_{2}-12\left(\delta_{\mathrm{H}} 2.12\right.$ and $2.00)$ and the chemical shift of C-16 $\left(\delta_{\mathrm{C}} 17.1\right)$ suggested the $E$ geometry of the $\Delta^{\mathbf{1 3 , 1 4}}$ double bond. The NOESY cross-peaks of $\mathrm{H}_{3}-17\left(\delta_{\mathrm{H}} 0.85\right) / \mathrm{H}-11 \mathrm{~b}\left(\delta_{\mathrm{H}} 1.24\right)$ and $\mathrm{H}-10\left(\delta_{\mathrm{H}} 1.41\right), \mathrm{H}-10 / \mathrm{H}-12 \mathrm{a}$ $\left(\delta_{\mathrm{H}} 2.12\right), \mathrm{H}_{2}-11\left(\delta_{\mathrm{H}} 1.83\right.$ and 1.24), $\mathrm{H}_{3}-19\left(\delta_{\mathrm{H}} 1.12\right)$ and $\mathrm{H}-6 \mathrm{a}$ $\left(\delta_{\mathrm{H}}\right.$ 1.62), and $\mathrm{H}_{3}-19 / \mathrm{H}-6 \mathrm{a}$ located $\mathrm{H}_{3}-17, \mathrm{H}-10, \mathrm{H}-6 \mathrm{a}$, and $\mathrm{H}_{3^{-}}$ 19 on the same face, while NOESY correlation of $\mathrm{H}_{3}-20\left(\delta_{\mathrm{H}} 1.01\right) /$ $\mathrm{H}-8\left(\delta_{\mathrm{H}} 1.55\right)$ positioned $\mathrm{H}_{3}-20$ and $\mathrm{H}-8$ on the opposite face (Fig. 6). Thus, the structure of 4 was assigned as a stereoisomer of agelasine $\mathrm{B}$ and named agelasine $\mathrm{V}$.

Compound 5, a pale yellow amorphous powder, had a molecular formula of $\mathrm{C}_{26} \mathrm{H}_{39} \mathrm{~N}_{5} \mathrm{O}$ deduced from the ${ }^{13} \mathrm{C} \mathrm{NMR}$ and HRESIMS (438.3229 $[\mathrm{M}+\mathrm{H}]^{+}$, calcd for $\mathrm{C}_{26} \mathrm{H}_{40} \mathrm{~N}_{5} \mathrm{O}$, 438.3233) data. Compound 5 possessed the same 8-oxo-9- $N$ methyladenine moiety according to the comparison of its $1 \mathrm{D}$

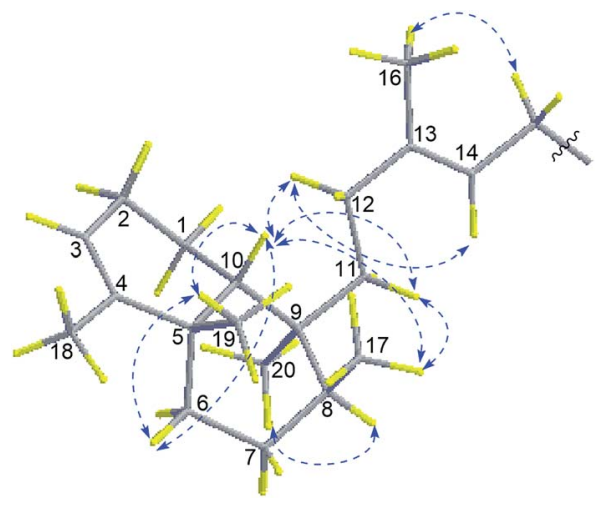

Fig. 6 Key NOESY correlations of compound 4.

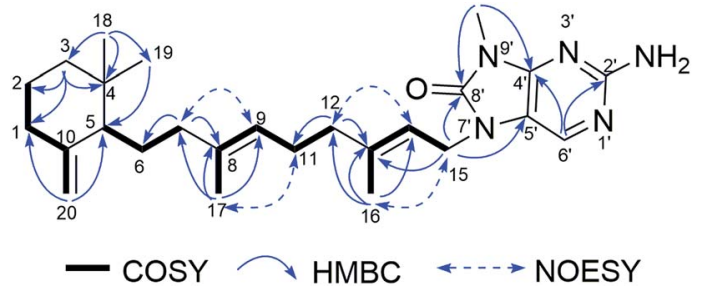

Fig. 7 Key ${ }^{1} \mathrm{H}-{ }^{1} \mathrm{H} C O S Y, H M B C$ and NOESY correlations of compound 5.

NMR data (Tables 1 and 2) with those of compound 1 . The rest 9, 10-seco-labdane skeleton was determined by analysis of 2D NMR data (Fig. 7). The configurations of the double bonds $\left(\Delta^{\mathbf{9 , 1 0}}\right.$ and $\left.\Delta^{\mathbf{1 3 , 1 4}}\right)$ were established as $E$ based on the NOESY correlations of $\mathrm{H}_{3}-17\left(\delta_{\mathrm{H}} 1.58\right) / \mathrm{H}_{2}-11\left(\delta_{\mathrm{H}} 2.11\right), \mathrm{H}-9\left(\delta_{\mathrm{H}} 5.03\right) /$ $\mathrm{H}_{2}-7\left(\delta_{\mathrm{H}} 1.74\right), \mathrm{H}_{3}-16\left(\delta_{\mathrm{H}} 1.82\right) / \mathrm{H}_{2}-15\left(\delta_{\mathrm{H}} 4.67\right)$, and $\mathrm{H}_{2}-12\left(\delta_{\mathrm{H}}\right.$ $2.11) / \mathrm{H}-14\left(\delta_{\mathrm{H}} 5.34\right)$ and the chemical shift of C-17 $\left(\delta_{\mathrm{C}} 16.1\right)$ and C-16 $\left(\delta_{\mathrm{C}}\right.$ 16.9). The absolute configuration of 5 was assumed to be the same as (+)-trixagol, whose enantiomer was equate to the terpenoid side chain of $(-)$-agelasine $\mathrm{E}$ in that they both exhibit positive optical rotations $\left[5\left([\alpha]_{\mathrm{D}}^{30}+30.6\right.\right.$, $\mathrm{MeOH}),(+)$-trixagol $\left([\alpha]_{\mathrm{D}}+14, \mathrm{CHCl}_{3}\right)^{29}$ and agelasine $\mathrm{E}$ $\left.\left([\alpha]_{\mathrm{D}}^{25}-17.1, \mathrm{MeOH}\right)^{20}\right]$. Accordingly, The structure of $(+)-8^{\prime}-$ oxo-agelasine E (5) was proposed as shown Fig. 1.

All isolated compounds were assessed for their antibacterial activity against a methicillin-susceptible $S$. aureus (MSSA) strain H608 and four methicillin-resistant S. aureus (MRSA) strains 2010-260, 2010-210, 2010-292, and 2010-300. As shown in Table 3, compounds 2 and 7 exhibited potent activities against MRSA with $\mathrm{MIC}_{90}$ values of 1-8 $\mu \mathrm{g} \mathrm{mL}^{-1}$ while other compounds showed no activity $\left(\mathrm{MIC}_{90}>64 \mu \mathrm{g} \mathrm{mL}{ }^{-1}\right)$. The cytotoxic activities of individual compounds were evaluated against the PC9, A549, HepG2, MCF-7, and U937 cell lines using Cell Counting Kit-8 (CCK-8) bioassay (Table 3). Compounds 2 and 7 showed moderate activities against the five cancer cell lines with $\mathrm{IC}_{50}$ values of 4.49-14.41 $\mu \mathrm{M}$. Other compounds showed no activity $\left(\mathrm{IC}_{50}>20 \mu \mathrm{M}\right)$ except compound 6 show weak cytotoxicity against U937 cell line with $\mathrm{IC}_{50}$ value of $16.89 \mu \mathrm{M}$. 
Table 3 Antibacterial and cytotoxic activities of compounds 1-7

Antibacterial activity against clinical $\mathrm{MRSA}^{d}$ and $\mathrm{MSSA}^{e}$ strains $\left(\mathrm{MIC}_{90}, \mu \mathrm{g} \mathrm{mL}{ }^{-1}\right)$

\begin{tabular}{|c|c|c|c|c|c|c|c|c|c|c|}
\hline Compounds $^{a}$ & $2010-260$ & $2010-210$ & $2010-292$ & $2010-300$ & H608 & PC9 & A549 & HepG2 & MCF-7 & U937 \\
\hline 2 & 2 & 1 & 2 & 1 & 2 & 5.08 & 14.07 & 9.76 & 7.64 & 4.49 \\
\hline 6 & $>64$ & $>64$ & $>64$ & $>64$ & $>64$ & $>50$ & $>50$ & $>50$ & $>50$ & 16.89 \\
\hline 7 & 4 & 4 & 8 & 8 & 1 & 4.49 & 14.41 & 10.07 & 5.47 & 6.86 \\
\hline Vancomycin $^{b}$ & 1 & 1 & 1 & 0.5 & 2 & & & & & \\
\hline Doxorubicin $^{c}$ & & & & & & 0.22 & 0.49 & 0.20 & 0.38 & 0.05 \\
\hline
\end{tabular}

${ }^{a}$ Compounds $\mathbf{1}$ and 3-5 were inactive in all assays. ${ }^{b}$ Positive control for antibacterial assay. ${ }^{c}$ Positive control for cytotoxic assay. ${ }^{d}$ Clinical MRSA strains 2010-260, 2010-210, 2010-292, 2010-300. ${ }^{e}$ Clinical MSSA strain H608.

\section{Conclusions}

In conclusion, five new diterpene alkaloids, illustrated by $(-)-8^{\prime}-$ oxo-agelasine B (1), (+)-agelasine B (2), (+)-8'-oxo-agelasine C (3), agelasine $\mathrm{V}(\mathbf{4}),(+)-8^{\prime}$-oxo-agelasine $\mathrm{E}(5)$, along with two known related metabolites, (-)-8'-oxo-agelasine D (6), agelasine D (7), were isolated from the marine sponge Agelas mauritiana. The structures of them were established by interpretation of spectroscopic data and comparison with literature properties. Isolation of compounds $\mathbf{1}$ and $\mathbf{3 - 5}$ provided new examples of $8^{\prime}$-oxoagelasine analogs. Compounds 2 and 7 showed potent antibacterial and moderate cytotoxic activities. Analysis of the structures of the diterpene alkaloids (1-7) and their antibacterial and cytotoxic activities led to a preliminary summary of the structureactivity relationship (SAR): C- $\mathbf{8}^{\prime}$-carbonylated compounds ( 1 and 3-6) can provide lower antibacterial and cytotoxic activities than other analogs (2 and 7). Moreover, the interesting antibacterial activity of compounds 2 and 7 indicated that they could be possible lead candidates as promising anti-MRSA agents.

\section{Experimental section}

\section{General experimental procedures}

Optical rotation data were measured in $\mathrm{MeOH}$ on an Autopol I polarimeter (no. 30575, Rudolph Research Analytical) with a $10 \mathrm{~cm}$ length cell. UV were recorded on a Hitachi U-3010 spectrophotometer. IR ( $\mathrm{KBr})$ spectra were obtained on Jasco FTIR-400 spectrometer. 1D and 2D NMR spectra were recorded in DMSO- $d_{6}$ or $\mathrm{CDCl}_{3}$ on a Bruker DRX-600 or on a Bruker DRX$400 \mathrm{MHz}$ NMR spectrometers. HRESIMS data was recorded on a Q-TOF micro YA019 mass spectrometer. Column chromatography (CC) was carried out on Sephadex LH-20 (Amersham Pharmacia Biotech AB), silica gel (200-300 mesh, Qingdao Marine Chemical Inc. China), and reverse phase C18 silica gel (15 $\mu \mathrm{m}$, Santai Technologies, Inc.). Analytical thin-layer chromatography was carried out using HSGF 254 plates and visualized by spraying with anisaldehyde- $\mathrm{H}_{2} \mathrm{SO}_{4}$ reagent. Reversedphase high-performance liquid chromatography (HPLC) was performed on Waters SunFire ${ }^{\mathrm{TM}}$ Prep C18 column $(5 \mu \mathrm{m}, 19 \times$ $150 \mathrm{~mm}$ ) with a Waters 1525 separation module equipped with a Waters 2998 photodiode array detector, and all solvents used for HPLC were of HPLC grade.

\section{Animal material}

Samples of Agelas mauritiana were collected along the coast of Yongxing Island in the South China Sea on March 19, 2013. A voucher specimen (no. 13-7) has been deposited at Research Center for Marine Drugs, State Key Laboratory of Oncogenes and Related Genes, Shanghai Jiao Tong University.

\section{Extraction and isolation}

The sponge (1.2 kg, wet weight) was cut and percolated with 95\% EtOH at room temperature to afford the crude extract (15.2 g), which was suspended in $\mathrm{H}_{2} \mathrm{O}$ and extracted with EtOAc. The EtOAc-soluble extract ( $9.3 \mathrm{~g}$ ) was concentrated under reduced pressure. Subsequently, the EtOAc-soluble extract was partitioned between $90 \%$ aqueous $\mathrm{MeOH}$ and petroleum ether to give $5.5 \mathrm{~g}$ petroleum ether-soluble fraction. The $90 \%$ aqueous $\mathrm{MeOH}$ fraction was diluted to $60 \%$ aqueous $\mathrm{MeOH}$ with $\mathrm{H}_{2} \mathrm{O}$ and extracted with $\mathrm{CH}_{2} \mathrm{Cl}_{2}$ to afford a $4.5 \mathrm{~g} \mathrm{CH}_{2} \mathrm{Cl}_{2}$-soluble fraction. This $\mathrm{CH}_{2} \mathrm{Cl}_{2}$-soluble extract was chromatographed on silica gel column eluting with a step gradient of $\mathrm{CH}_{2} \mathrm{Cl}_{2}-\mathrm{MeOH}$ $(100: 1$ to $0: 1)$ to give nine fractions (DA-DI). Fraction DH (1.1 g) was subjected to VLC over silica gel eluting with a $\mathrm{CH}_{2} \mathrm{Cl}_{2}-$ EtOAc-MeOH- $\mathrm{H}_{2} \mathrm{O}$ system $(10: 5: 1.5: 0.2$ and $0: 0: 1: 0)$ to afford four subfractions (DH1-DH4). Subfraction DH3 (200.1 $\mathrm{mg}$ ) was directly separated by reversed-phase HPLC (Waters SunFire $^{\mathrm{TM}}$ Prep C18, $5 \mu \mathrm{m}, 19 \times 150 \mathrm{~mm} ; 10.0 \mathrm{~mL} \mathrm{~min}^{-1} ; 210$, $270 \mathrm{~nm}$ ) eluting with a $\mathrm{CH}_{3} \mathrm{CN}-\mathrm{H}_{2} \mathrm{O}-\mathrm{TFA}$ system (50:50:0.1) to give $(+)$-agelasine $\mathrm{B}\left(2,40.0 \mathrm{mg}, t_{\mathrm{R}} 8.5 \mathrm{~min}\right)$ and agelasine $\mathrm{D}(7$, $\left.35.2 \mathrm{mg}, t_{\mathrm{R}} 10.0 \mathrm{~min}\right)$. DH1 (163.6 mg) was subjected to silica gel column chromatography, using a gradient of $\mathrm{CH}_{2} \mathrm{Cl}_{2}$-EtOAc$\mathrm{MeOH}-\mathrm{H}_{2} \mathrm{O}$ solvent system (50 : 5:1 : $0.1,45: 5: 1: 0.1,40: 5: 1: 0.1$, $25: 5: 1: 0.1, \quad 20: 5: 1: 0.1, \quad 20: 5: 1: 0.1, \quad 10: 5: 1.25: 0.2$, and $0: 0: 1: 0)$ to give 5 subfractions (DH1A-DH1E). Subfraction DH1B (60.5 mg) was further purified by reversed-phase HPLC (Waters SunFire $^{\mathrm{TM}}$ Prep C18, $5 \mu \mathrm{m}, 19 \times 150 \mathrm{~mm}$; $9.0 \mathrm{~mL} \mathrm{~min}^{-1}$; 210, 270 $\mathrm{nm}$ ) eluting with a $\mathrm{CH}_{3} \mathrm{CN}-\mathrm{H}_{2} \mathrm{O}-\mathrm{TFA}(55: 45: 0.1)$ system to give (-)-8'-oxo-agelasine $\mathrm{B}\left(\mathbf{1}, 15.0 \mathrm{mg}, t_{\mathrm{R}} 49.5 \mathrm{~min}\right),(-)-8^{\prime}$-oxo-agelasine $\mathrm{D}\left(6,13.1 \mathrm{mg}, t_{\mathrm{R}} 55.0 \mathrm{~min}\right),(+)-8^{\prime}$-oxo-agelasine C (3, $5.7 \mathrm{mg}, t_{\mathrm{R}} 63.9$ $\mathrm{min})$, agelasine $\mathrm{V}\left(\mathbf{4}, 2.8 \mathrm{mg}, t_{\mathrm{R}} 52.0 \mathrm{~min}\right),(+)-8^{\prime}$-oxo-agelasine $\mathrm{E}(5$, $\left.2.9 \mathrm{mg}, t_{\mathrm{R}} 70.0 \mathrm{~min}\right)$.

(-)-8'-Oxo-agelasine B (1). Pale yellow amorphous powder; $[\alpha]_{\mathrm{D}}^{25}-33.9(c 0.11, \mathrm{MeOH}) ; \mathrm{UV}(\mathrm{MeOH}) \lambda_{\max }(\log \varepsilon) 216$ (4.07), 
275 (3.64) nm; IR (KBr) $\nu_{\max }$ 3325, 2927, 2861, 1718, 1639, 1460, 1376, 1198, $1141 \mathrm{~cm}^{-1} ;{ }^{1} \mathrm{H}$ and ${ }^{13} \mathrm{C}$ NMR data, see Tables 1 and 2; HRESIMS $m / z$ 438.3232 $[\mathrm{M}+\mathrm{H}]^{+}$(calcd for $\mathrm{C}_{26} \mathrm{H}_{40} \mathrm{~N}_{5} \mathrm{O}$, 438.3233).

(+)-Agelasine $\mathrm{B}$ (2). Pale yellow amorphous powder; $[\alpha]_{\mathrm{D}}^{30}+22.7(c 0.10, \mathrm{MeOH}) ; \mathrm{UV}(\mathrm{MeOH}) \lambda_{\max }(\log \varepsilon) 214$ (4.16), 262 (3.63) nm; IR (KBr) $\nu_{\max } 3320,2927,2858,1683,1649,1460$, 1379, 1202, 1133, 798, $720 \mathrm{~cm}^{-1} ;{ }^{1} \mathrm{H}$ and ${ }^{13} \mathrm{C}$ NMR data, see Tables 1 and 2; HRESIMS $m / z 422.3280[\mathrm{M}+\mathrm{H}]^{+}$(calcd for $\left.\mathrm{C}_{26} \mathrm{H}_{40} \mathrm{~N}_{5}, 422.3284\right)$.

(+)-8'-Oxo-agelasine $\mathbf{C}$ (3). Pale yellow amorphous powder; $[\alpha]_{\mathrm{D}}^{25}+29.0(c 0.08, \mathrm{MeOH}) ; \mathrm{UV}(\mathrm{MeOH}) \lambda_{\max }(\log \varepsilon) 214$ (4.00), 274 (3.50) nm; IR (KBr) $\nu_{\max } 3325,2925,2856,1721,1640,1459$, 1373, 1197, $1142 \mathrm{~cm}^{-1} ;{ }^{1} \mathrm{H}$ and ${ }^{13} \mathrm{C}$ NMR data, see Tables 1 and 2; HRESIMS $m / z$ 438.3231 $[\mathrm{M}+\mathrm{H}]^{+}$(calcd for $\mathrm{C}_{26} \mathrm{H}_{40} \mathrm{~N}_{5} \mathrm{O}$, 438.3233).

Agelasine V (4). Pale yellow amorphous powder; $[\alpha]_{\mathrm{D}}^{30}+36.5(c$ 0.08, MeOH); UV (MeOH) $\lambda_{\max }(\log \varepsilon) 214$ (3.62), 275 (3.12) nm; IR (KBr) $\nu_{\text {max }} 3330,2926,2856,1721,1641,1461,1375,1198$, 1092, $802 \mathrm{~cm}^{-1} ;{ }^{1} \mathrm{H}$ and ${ }^{13} \mathrm{C}$ NMR data, see Tables 1 and 2; HRESIMS $m / z$ 438.3230 $[\mathrm{M}+\mathrm{H}]^{+}$(calcd for $\mathrm{C}_{26} \mathrm{H}_{40} \mathrm{~N}_{5} \mathrm{O}$, 438.3233).

(+)-8'-Oxo-agelasine E (5). Pale yellow amorphous powder; $[\alpha]_{\mathrm{D}}^{30}+30.6(c 0.11, \mathrm{MeOH}) ; \mathrm{UV}(\mathrm{MeOH}) \lambda_{\max }(\log \varepsilon) 203$ (3.58), 275 (3.03) nm; IR (KBr) $\nu_{\max } 3325,2925,2856,1721,1640,1459$, 1373, 1197, $1142 \mathrm{~cm}^{-1} ;{ }^{1} \mathrm{H}$ and ${ }^{13} \mathrm{C}$ NMR data, see Tables 1 and 2; HRESIMS $m / z$ 438.3229 $[\mathrm{M}+\mathrm{H}]^{+}$(calcd for $\mathrm{C}_{26} \mathrm{H}_{40} \mathrm{~N}_{5} \mathrm{O}$, 438.3233).

\section{Antibacterial assay}

The in vitro antibacterial assay was carried out as reported before. ${ }^{30}$ Vancomycin was used as positive control and displayed $\mathrm{MIC}_{90}$ values of $2,1,1,1$, and $0.5 \mu \mathrm{M}$ against methicillinsusceptible $S$. aureus strain $\mathrm{H} 608$ and methicillin-resistant $S$. aureus strains 2010-260, 2010-210, 2010-292, and 2010-300, respectively.

\section{Cytotoxicity assay}

The effects of 1-7 on cell viability was determined using the Cell Counting Kit-8 (CCK-8). The human PC9, A549, HepG2, MCF-7, and $\mathrm{U} 937$ cell lines were obtained from the Institute of Biochemistry Cell Biology (Shanghai, China). Cells were seeded in 96 well plates $\left(5 \times 10^{3}\right.$ cells per well). After $24 \mathrm{~h}$ incubation, the cells were treated with various concentrations of 1-7 for $72 \mathrm{~h}$. Then the CCK8 solution $(10 \mu \mathrm{L})$ was added for additional $1 \mathrm{~h}$ incubation at $37{ }^{\circ} \mathrm{C}$. The absorbance at $450 \mathrm{~nm}$ was measured in a microplate reader (spectra MAX190, Molecular Devices, USA). Independent experiments were performed in triplicate.

\section{Acknowledgements}

This research was supported by the National Natural Science Fund for Distinguished Young Scholars of China (81225023), the National Natural Science Fund of China (No. U1605221, 41428602, 41576130, 81502936, 41476121 and 81402844), and the Fund of the Science and Technology Commission of Shanghai Municipality (No. 14431901300 and 15431900900).

\section{Notes and references}

1 M. Mehbub, J. Lei, C. Franco and W. Zhang, Mar. Drugs, 2014, 12, 4539-4577.

2 J. W. Blunt, B. R. Copp, R. A. Keyzers, M. H. G. Munro and M. R. Prinsep, Nat. Prod. Rep., 2016, 33, 382-431.

3 Y. Zhu, Y. Wang, B.-B. Gu, F. Yang, W.-H. Jiao, G.-H. Hu, H.-B. Yu, B.-N. Han, W. Zhang, Y. Shen and H.-W. Lin, Tetrahedron, 2016, 72, 2964-2971.

4 T. Yasuda, A. Araki, T. Kubota, J. Ito, Y. Mikami, J. Fromont and J. i. Kobayashi, J. Nat. Prod., 2009, 72, 488-491.

5 D. B. Abdjul, H. Yamazaki, S.-i. Kanno, O. Takahashi, R. Kirikoshi, K. Ukai and M. Namikoshi, J. Nat. Prod., 2015, 78, 1428-1433.

6 J. J. La Clair and A. D. Rodríguez, Bioorg. Med. Chem., 2011, 19, 6645-6653.

7 Y. Tanaka and T. Katayama, Nippon Suisan Gakkaishi, 1982, 48, 531-533.

8 J.-F. Hu, M. Kelly and M. T. Hamann, Steroids, 2002, 67, 743747.

9 D. Tasdemir, B. Topaloglu, R. Perozzo, R. Brun, R. O'Neill, N. M. Carballeira, X. Zhang, P. J. Tonge, A. Linden and P. Rüedi, Bioorg. Med. Chem., 2007, 15, 6834-6845.

10 H. Nakamura, H. Wu, J. i. Kobayashi, Y. Ohizumi, Y. Hirata, T. Higashijima and T. Miyazawa, Tetrahedron Lett., 1983, 24, 4105-4108.

11 H. Nakamura, H. Wu, J. Kobayashi, M. Kobayashi, Y. Ohizumi and Y. Hirata, J. Org. Chem., 1985, 50, 2494-2497.

12 F. Yang, M. T. Hamann, Y. Zou, M.-Y. Zhang, X.-B. Gong, J.-R. Xiao, W.-S. Chen and H.-W. Lin, J. Nat. Prod., 2012, 75, 774-778.

13 A. Medeiros Maria, A. Lourenço, R. Tavares Maria, M. Curto Maria João, S. Feio Sónia and C. Roseiro José, Zeitschrift für Naturforschung C, 2006, 61, 472-476.

14 J. J. Morales and A. D. Rodríguez, J. Nat. Prod., 1992, 55, 389394.

15 E. P. Stout, L. C. Yu and T. F. Molinski, Eur. J. Org. Chem., 2012, 2012, 5131-5135.

16 R. J. Capon and D. J. Faulkner, J. Am. Chem. Soc., 1984, 106, 1819-1822.

17 H. Nakamura, H. Wu, Y. Ohizumi and Y. Hirata, Tetrahedron Lett., 1984, 25, 2989-2992.

18 L. Calcul, K. Tenney, J. Ratnam, J. H. McKerrow and P. Crews, Aust. J. Chem., 2010, 63, 915-921.

19 T. Hattori, K. Adachi and Y. Shizuri, J. Nat. Prod., 1997, 60, 411-413.

20 H. Wu, H. Nakamura, J. i. Kobayashi, Y. Ohizumi and Y. Hirata, Tetrahedron Lett., 1984, 25, 3719-3722.

21 K. Ishida, M. Ishibashi, H. Shigemori, T. Sasaki and J. Kobayashi, Chem. Pharm. Bull., 1992, 40, 766-767.

22 X. Fu, F. J. Schmitz, R. S. Tanner and M. Kelly-Borges, J. Nat. Prod., 1998, 61, 548-550.

23 J. Appenzeller, G. Mihci, M.-T. Martin, J.-F. Gallard, J.-L. Menou, N. Boury-Esnault, J. Hooper, S. Petek, 
S. Chevalley, A. Valentin, A. Zaparucha, A. Al-Mourabit and C. Debitus, J. Nat. Prod., 2008, 71, 1451-1454.

24 T. Kubota, T. Iwai, A. Takahashi-Nakaguchi, J. Fromont, T. Gonoi and J. i. Kobayashi, Tetrahedron, 2012, 68, 97389744.

25 R. Fathi-Afshar and T. M. Allen, Can. J. Chem., 1988, 66, 4550.

26 G. R. Pettit, Y. Tang, Q. Zhang, G. T. Bourne, C. A. Arm, J. E. Leet, J. C. Knight, R. K. Pettit, J.-C. Chapuis, D. L. Doubek, F. J. Ward, C. Weber and J. N. A. Hooper, J. Nat. Prod., 2013, 76, 420-424.
27 E. Piers and J. Y. Roberge, Tetrahedron Lett., 1992, 33, 69236926.

28 I. S. Marcos, N. García, M. J. Sexmero, P. Basabe, D. Díez and J. G. Urones, Tetrahedron, 2005, 61, 11672-11678.

29 A. K. Bakkestuen and L.-L. Gundersen, Tetrahedron, 2003, 59, 115-121.

30 W.-H. Jiao, J. Li, Q. Liu, T.-T. Xu, G.-H. Shi, H.-B. Yu, F. Yang, B.-N. Han, M. Li and H.-W. Lin, Molecules, 2014, 19, 1802518032. 